\title{
The Advantages of Personal Documentation Video in Improving Students' Speaking Skill for Presentation
}

\author{
Madya Giri Aditama ${ }^{1}$, Dwi Haryanti ${ }^{2}$ Musiman $^{3}$ Fitria Wulan Sari ${ }^{4}$
}

\author{
${ }^{1}$ Department of English Education, STKIP Muhammadiyah Batang, Indonesia \\ ${ }^{2}$ Department of English Education, Universitas Muhammadiyah Surakarta, Indonesia \\ ${ }^{3}$ Department of English Education, Universitas Muhammadiyah Lampung, Indonesia \\ ${ }^{4}$ Department of English Education, Universitas Khairun, Indonesia \\ *Corresponding author. Email: mgaditama@mbstkip.ac.id
}

\begin{abstract}
Speaking is one of the most important skills in English. Speaking English in public is difficult for Indonesian students because English is learnt as foreign language. Speaking practice should be done continually and effectively. Personal presentation is used as a practice method for students to be able to speak in public. By combining digital technology and education, the objectives of this study are (1) classifying the time allotment of personal documentation video done by students; (2) describing the topics of personal documentation video done by students; (3) describing the speaking problems faced by students; and (4) classifying the advantages of students by composing personal documentation video. This descriptive qualitative study analyzed data in the form of speaking recorded in video projects done by students and interviewed result with the students. After classifying the data based on the duration of the videos, it was found that there are 21 videos $(25,30 \%)$ which have duration less than 7 minutes, 52 videos $(62,65 \%)$ which fulfill the duration requirement in $7-10$ minutes, and there are 10 videos $(12,05 \%)$ which have more than 10 minutes duration. It shows students' vocabulary mastery in describing something. The common topics used by students in the project were hometown, hobbies, describing things, and tourism or travel experiences. This study found that the common problem in speaking is the lack of confidence caused by the lack of vocabulary, grammar, fluency and pronunciation. This study also finds the advantages of students' developments in speaking skill for presentation after composing personal documentation video project.
\end{abstract}

Keywords: Personal Documentation Video, Speaking, English

\section{INTRODUCTION}

In Indonesia, English should be learnt as a foreign language and it is not easy. In learning English, learners should master four skills in it. They are listening, reading, writing, and speaking. Speaking is one of the most important competences in studying English. By doing personal presentation, students tend to practice their selves to speak in public. Iftakhar [14] stated that students' ability to speak in English accurately and fluently ensured their communicative competence in English. Speaking is one of the primary skills which are developed very naturally. The aim of Communicative Language Teaching is to develop students' communicative competence by engaging them in meaningful interaction. According to Huebner [12] "Speaking is a skill used by someone in daily life communication by much repetition; it primarily a neuromuscular and not an intellectual process. It consists of competence in sending and receiving messages". Mastering the skill of speaking is the most important aspect of learning in second or foreign language and success is measured based on the ability to perform a conversation in the language [19].
Harrison [10] in his book The Literate Imagination mentioned that learners need to be confident and expert in talking, so that they will be capable in:

a.listening, conveying and sharing ideas and feeling

b.listening, conveying and sharing information

c.understanding, conveying and sharing the story of their own or others'

d.listening, present defending and interrogating points of view;

e.considering questions, raising questions, working towards answers;

f. understanding accounts of processes, be able in describing and evaluating processes

g.being sensitive (as listener and as speaker) for appropriate tone and rhythms of voice - for example, sometimes reflective and exploratory, at other times assertive and persuasive;

h.being aware (as listener and as speaker) of the need for clear expression;

i. knowing when to be tolerant, when to support and when to challenge in talk with others; 
j. being confident in providing a personal presence in talking, without letting self-consciousness intrude on what you want to say and accept the personal presence of others, while respecting what they have to say (rather than how they say it).

The lack of speaking ability for Indonesian students is one of worried problem in developing Indonesian education. Students need to practice speaking more in order they can be able to improve their active confidence and vocabulary mastery. In this digital era, we can learn and practice speaking English by using digital media. Digital media which are used by people to create many videos have variety of contents but only few of them are useful for learning. By using digital media, the researcher tries to combine digital literacy in practicing speaking English. The condition of Students' speaking ability is good, however the lack of speaking practice pushed them to be passive and by the time it decreases their ability. The usage of digital media and social media as platform of expression creates a lot of idea to perform by using this video project. Reedy [22] stated that digital literacy referred to an individual's ability in finding, evaluating, and composing clear information through writing and other media on various digital platforms. He defined digital literacy was evaluated by an individuals' grammar, composition, the skills in typing and text production ability, audio, images and designs using technology. The ability to operate digital media is one of important skills for students to survive in this era. Warschauer and Matuchniak [30] listed three skill sets which individuals needed to master in order to be digitally literate in 21 st century, they were: information, media, and technology; learning and innovation skills; and life and career skills.

By keep fulfilling the role of the teacher according to Harmer [9] in his book The Practice of English Language Teaching, pointed out three different roles which the teacher needs to play to get students able to speak fluently:

a. Prompter:

Sometimes during speaking, students might get lost i.e. they are not able to say what to say next. "Sometimes, when students are involved in a role-play activity, for example, they lose the thread of what is going on, or they are 'lost for words' (i.e. they might still have the thread but be unable to proceed productively for lack of vocabulary). They may not be quite sure how to proceed." [9].

\section{b. Participant:}

Harmer [9] defined that by taking a role as participant, the teachers can prompt covertly, introduce new information in purpose to help the activity along, ensure continuing students' engagement, and generally maintain a creative atmosphere'. c. Feedback provider:

Harmer [9] mentioned that teachers' feedback is important in students' speaking activities. In this regard, the teacher should avoid over-correction. A helpful and gentle correction will make the students to be confident and it 'may get students out of difficult misunderstanding and hesitations. The methodologist Lynch [13] argues that the students learn many things from the problems that they face while speaking. By facing problem, students feel challenged to develop and improve to be better.

In combining digital media in learning Speaking English, the researcher proposed a learning method called "Personal Documentation Video". This method aims to improve students' confidence and ability to do public speaking. Goodwin [6] and Hall [8] agreed that video uncovered a wide range of interactional modalities; people tend to use talk, gesture, gaze, body position, facial expression, movement, and material objects in exchanging ideas and information. This method facilitates students to express their speaking ability freely without pressure of audience. Speaking is strongly bounded with vocabulary. By practicing a lot, students tend to acquire more vocabulary. Vocabulary played a significant role in communication, because the communication would be stopped if people hear or read words which people fail to understand [25]. According to Schmitt [24], vocabulary is the center of learning and communication. This method conducted because of the phenomenon in social media where there are a lot of children and teenagers make a lot of self-recorded video which has useless contents and unrelated to study or education. The literature on using video in the study of teaching and learning provides guidance for researchers to select, to capture, and to represent video data [4]. It has been suggested that teaching vocabulary should not only consist of teaching specific words but also intended in equipping learners with strategies necessary to expand their knowledge about vocabulary [18]. In this project, students tend to create a personal / individual documentation video by recording their performance in speaking English. Each student tends to describe and present their own favorite topic. Teacher as facilitator gave the instruction about steps to make a speech and the execution is on their own creativity. Lucas [16] also supports this view and suggests that preparation is must for speaking activities. That's why the concept before recording should be prepared carefully by each student.

\subsection{Personal Documentation Video}

In the needs to be emphasizes, the level to practice speaking English is suited with three most commonly used organizational forms of teaching speaking: Whole-class 
teaching, Group -work, and Pair work. Where this project modify it by individual project "Personal Documentation Video", pair project "Pair Video Story", and last is group project "Mini Movie".

\section{a.Individual Project "Personal Documentation Video"}

This project level follows Richards and Lockhart [23] whole-class teaching principles. They mentioned that in whole-class teaching the teacher led the whole-class through a learning task. In another hand, Harmer [9] named the whole-class teaching as 'lockstep method' and mentions, "Lockstep is the class grouping where all the students are working with the teacher, where all the students are 'locked into' the same rhythm and pace, the same activity, where a teacher-controlled session is taking place" So in this level, the topic and the competence level is same for all students in the class. Each student conducts a project where they have to describe a topic and present it in a documentation video. This is an individual task, so the students should prepare the topic, develop the speech and record their own presentation by themselves; the duration of the video is 7 - 10 minutes.

\section{b.Pair project "Pair Video Story"}

In pair work, the teacher divides the students in the class into pairs. Students need to work together as a pair in this project. They have to work together in choosing topic, develop the speech and in recording. Byrne [1] mentioned that "In pair work, the teacher divides the whole class into pairs. Every student works with his or her partner, and all the pairs work at the same time". He considered that pair works as an interaction similar to real-life language use. "They [learners] can face and talk directly to one another, so it is much closer to the way we [people] use language outside the classroom" [1]. In this project, students can interact and communicate each other and do a discussion regarding the topic they presented.

\section{c. Group project "Mini Movie"}

In group project, the teacher divides the students in the class into some small groups. Each group consists of 9 12 students. Each student in the group should give contribution in doing the project together with their group member. Ur [28] agreed that group work provided some learners with confidence and courage. "Students, who are shy of speaking in front of the whole class, or to the teacher, often find it much easier to express themselves in front of a small group of their peers". By working together with friends or partners they've known, student will be able to express their thought and idea freely without pressure. Richards and Lockhart [23] mentioned that group work will be able to increase the amount of student participation in the class and promote collaboration among learners.

\section{OBJECTIVES}

Based on the phenomena mentioned in the previous part, the objective of this article are (1) classifying the time allotment of personal documentation video done by students; (2) describing the topics of personal documentation video done by students; (3) describing the speaking problems faced by students; and (4) classifying the advantages of students by composing personal documentation video.

\section{APPROACH \& RESEARCH METHOD}

This is descriptive qualitative study. The data were videos' content done by students and interviewed result from the students. The data consist of 83 videos and informants. The informants are 21 civil engineering students, 30 students of management Department, 11 students of mechanical engineering, and 21 Islamic education department students. The data were collected through documentation method by using content analysis technique and interviewed with international classes' students of $\mathrm{s}$ Muhammadiyah University of Surakarta who joined English for International Class in the Second Semester. Content analysis has been defined as a systematic, replicable technique for compressing many words of text into fewer content categories based on explicit rules of coding [23]. The data validity in this study, the writers used triangulation of data sources by using document of personal documentation video and informants of interview records with the students, also triangulation of technique of data collecting, which are documentation and interview. Patton [20] stated that triangulation referred to the use of multiple methods or data sources in doing qualitative research to develop a comprehensive understanding of phenomena. Denzin [3] and Patton [20] classified four types of triangulation, they were: (a) method triangulation, (b) investigator triangulation, (c) theory triangulation, and (d) data source triangulation. Method triangulation involves the use of multiple methods of data collection about the same phenomenon [21].

The data were analyzed by using Nunan, Thornbury, Hudges's theory of speaking; Richard \& Lockhards' theory of content analysis and Goodwin and Hall's theory of video project through observation method. Gorman and Clayton [7] defined observation studies as those that "involve the systematic recording of observable phenomena or behavior in a natural setting". A total of 83 data were observed to find out the problems and solution in speaking English by following these steps: (1) classifying the time allotment of personal documentation video done by students; (2) 
describing the topics of personal documentation video done by students; (3) describing the speaking problems faced by students; and (4) classifying the advantages of students by composing personal documentation video.

\section{RESULT \& DISCUSSION}

Personal Documentation Video is a project that assigned to the students where the purpose is to facilitate students to express their thought, idea and ability in speaking English freely and fun. This study analyzed the videos made by students followed by interview to the students about speaking and the project they have done.

\subsection{The Time Allotment of Personal Documentation Video.}

Personal Documentation Video is an individual task, so the students should prepare the topic, develop the speech and record their own presentation by themselves; the duration of the video is $7-10$ minutes. Each student conducted a project where they have to describe a topic and presented it in a documentation video.

Table 1 Students' Videos Duration

\begin{tabular}{|l|c|c|}
\hline Duration of videos & $\begin{array}{c}\text { Number of } \\
\text { Students }\end{array}$ & Percentage \\
\hline Less than 7 Minutes & 21 & $25,30 \%$ \\
\hline 7-10 Minutes & 52 & $62,65 \%$ \\
\hline More than 10 Minutes & 10 & $12,05 \%$ \\
\hline Total & $\mathbf{8 3}$ & $\mathbf{1 0 0 \%}$ \\
\hline
\end{tabular}

After classifying the data source based on the duration of the videos, it was found that there are 21 videos $(25,30 \%)$ which have duration less than 7 minutes, 52 videos $(62,65 \%)$ which fulfill the duration requirement in $7-10$ minutes, and there are 10 videos $(12,05 \%)$ which have more than 10 minutes duration. From the duration of the videos, it can be seen that students who made videos which have longer duration have more idea and more topic development in their videos. The description development of the topic showed that the author of the videos used more vocabulary in their speaking. One cannot convey his message effectively or express his ideas in both oral and written forms without a sufficient vocabulary [5]. Another factor which can be determined by looking at the duration is the amount of slides and descriptions which supported the topic described.

\subsection{The Topic of Personal Documentation Videos Done by Students.}

Based on the analysis of videos content and interview result, it shown that there were some favorite topics chosen by the students in their presentation. Those topics are hometown, hobbies, describing things, and tourism or travel experiences. These results also supported by students' interview results, which is stated the same things.

\section{a. Hometown}

By following descriptive text structure, students describe the specific and unique things about their hometown. There are 24 students chosen this topic. They explained the location, situation, unique cultures, food and interesting things can be found in their hometown. They tended to use variety kinds of vocabularies in describing hometown.

\section{b.Hobbies}

In this topic, students shared their own hobbies and the reason why they choose it. It was found 16 videos conducted this topic. Students tended to explain about their hobby, what it is, how to do it, how many times they do it, and why it is benefit for them. By explaining those aspects, students develop many vocabularies and dictions in explaining each aspect. This topic enforced students to active in finding reasons to explain about their hobbies.

\section{c.Describing Things}

This topic is general. There are 32 students choose this topic. Students have their own choice to describe anything. Some students describe about books, cooking tutorial, favorite item, natural phenomenon, social phenomenon, and other. By following descriptive texts' structure, students describe many things in specific. They supported their description by using picture, number, and argument. This topic tended to push students to enrich their diction and vocabulary especially about specific things regarding their topic.

d.Tourism or Travel Experiences

By following recount texts' structure, 11 students shared their own experiences in doing trip. They shared the location, situation, the way to the destination and other This topic pushed students to use the right grammar to describe it. The choice of diction and vocabulary should be suitable to the topic described. In describing tourism destination, students also tended to promote the beauty and unique things about it. 
Each topic has their own difficulties, choice of dictions, vocabularies, the use of grammar, the use of tone and intention in presentation. All of those aspects were part of students speaking contents in the video analyzed. The ability to maximize and develop the idea into a great presentation required experiences and background knowledge of each student.

After classifying the data, it can be seen that the varieties of video durations done by the students shows the difference of students' vocabulary mastery. Supported by the interview result about students' English acquisition background, student's perspectives to the speaking English and Personal Documentation Video project were conducted by one-on-one method. Based on the interviewed questions, it can be described that students of international classes in Muhammadiyah University of Surakarta who followed second English for International Class have different background of learning English. There are 32 students $(38,55 \%)$ stated that they have been studying English for around 7 years started at junior high school, while other 51 students $(61,45 \%)$ said that they've been acquiring English for 8 - 9 years, it was started since they were on 5th grade of primary school.

\subsection{Speaking Problems Faced by Students.}

Regarding the problem in speaking English, all students agree that they face the same problems. Based on the interview result, while speaking in English they feel nervous and shy. This is because they feel that they lack in Vocabulary, grammar, fluency and pronunciation. Majority of the students had no previous experience in speaking in English outside the class.

\section{a. Vocabulary}

Vocabulary mastery gave huge impact to students in developing idea. While preparing the project, students tend to prepare a topic and develop it into a good presentation. The lack of vocabulary mastered by students made students do repetition in speaking. Self-correction and explain the meaning also done by students in their performance.

\section{b. Grammar}

According to Thornbury [27], learners' correct use of grammatical structures requires the length and complexity of the utterances and the well-structured clauses. Selecting suitable words in the suitable contexts tend to gain accuracy in terms of vocabulary. After analyzing the data, found that some students made mistakes in the use of grammar. Incorrect use of tenses in students' performance becomes common problem faced by students.

\section{c.Fluency}

According to Hughes [13], fluency is the learners' ability to speak in understandable way in order not to break down communication because listeners may lose their interest. While Hedge [11], expressed that fluency is the ability to answer coherently by connecting the words and phrases, pronouncing the sounds clearly, and using stress and intonation. Based on the analysis of the videos done by students, it is found that the difficulties in pronouncing, intonation, and still memorizing the text become problem faced by students in speaking fluently.

\section{d.Pronunciation}

Thornbury [27] declared that pronunciation is the lowest level of knowledge learners typically pays attention to it. Learners should also know about stress, intonation, and pitch. These elements help learners speak the English easily and effectively. Based on students' video analysis, the pronunciation problems are caused by students' lack of pronouncing practice, doubting in speaking, miss use in stress and unconfident.

The problems of speaking faced by students above supported by the interview result where all students agreed that the important things in public speaking are confidence, fluency, developing idea and experience. They mentioned that one or two semester is not enough to develop the speaking skill; it needs a lot of practices to be able to speak fluently. They need more time to be confident to speak and to present something before an audience with fluency and grammatical accuracy.

In the process of conducting this project, the 21 students $(25,30 \%)$ said that they've made such kind of video project before, while the rest of 62 students $(74,70 \%)$ never did. That's why most students have difficulties in doing this project, especially regarding the technical matter. Developing Idea, recording process and editing process are the most common problems stated by the students while finishing Personal Documentation Video project. This is where teacher/lecturer needs to guide students by giving feedback and instruction to the students. Krashen [15] also said that a lot of affective variables have been connected to second language acquisition and motivation, selfconfidence, and anxiety were the three main types that have been investigated by many researchers.

\subsection{The Advantages of Students by Composing Personal Documentation Video.}

After doing the projects, the videos were submitted and evaluated together to examine how far this projects useful to help students improve their speaking skill. All students agree that they become more confident and brave enough to speak outside of class and they want to do other projects which can be used as learning practice for them.

a. Vocabulary

The main purpose of this video project is to improve students' confidence in speaking also develop students' vocabulary mastery by doing repetition of practice while preparing and conducting this project. By recording their performance in speaking English, students are able to show their true ability in speaking without any pressure of audience because they only speak in front of camera. By 
the process of doing video project, students tend to practice in developing idea so they also mastering vocabulary more than before. The choice of new dictions and unfamiliar vocabularies by the students reflected in video project is shown by the following excerpt:

"Bunaken National Park is representative of Indonesian tropical water ecosystems, consisting of sea grass plain, coral reef, and coastal ecosystem"

\section{b.Grammar}

Students acquire more vocabularies and the use of grammar especially regarding hometown, hobbies, describing things, and tourism or travel experiences as the topics chosen by students in conducting this project. By developing description following the topic, students tend to make suitable choice of tenses. Such as in describing things, students follow the generic structure of descriptive text so the language features also fulfilled. In the topic of "travel experiences" students need to follow the generic structure of recount text, so the language features and the use of past tenses should be appropriate to the topic developed.

\section{c. Fluency}

By doing repetition in preparing the project, students forced to memorize not only the vocabulary but also the way it is spoken. The more students repeat their performance, they become more fluently in the future.

\section{d.Pronunciation}

Following the same steps in preparing the project, students tend to prepare the topic, developing idea practicing and presenting. In preparing to deliver the best performance, students tried to practice their performance. The more they practice; they will become better in pronouncing words in their presentation. This project enforced students to practice speaking by only following the steps in preparing their performance.

Teacher and environment should motivate students so they talk a lot inside and outside classroom. Ur [29] supported this point of view. To motivate the learner, teachers must welcome meaningful noise of the interaction in the speaking class. Chambers [2] claimed that our learners are image conscious teenagers" who are alert not to make mistake in speaking, so they keep silent. That's why students need a lot of practices in speaking English, especially for Indonesian students who learn English as second language.

\section{CONCLUSION}

Speaking is one important skill in English. The ability to speak fluently and confidently is crucial. Especially for international classes students who should be able to compete and follow international standard in education. Personal Documentation Video is one method to practice speaking English freely and fun. By using digital media, learning and practicing be easier and more effective. Confidence, fluency, developing idea and experience are common obstacles which faced by students in speaking English. While developing idea or topic, recording process and editing process are the most common problems stated by the students while finishing Personal Documentation Video project. However the result of this project gave positive impact in improving students' ability in speaking English is worth to be developed. The object of the project in this study is university students, but this learning method also applicable to junior and senior high school students, as long as they have gadget, the can do this kind of project even more improved. Teacher or lecturer's guidance are needed to make students enthusiastic finishing this project. Personal Documentation Video can be one effective method to practice speaking English in this digital era.

\section{ACKNOWLEDGMENT}

This work was supported by English Education Department STKIP Muhammadiyah Batang and English for International Class Program conducted by Language Centre of Universitas Muhammadiyah Surakarta.

\section{REFERENCES}

[1] Byrne, D. (1991). Techniques for Classroom Interaction. Cambridge: Cambridge University Press.

[2] Chambers, G. (1999). Motivating Language Learners. Clevedon: Multilingual Matters Ltd.

[3] Denzin, N.K. (1978). Sociological methods: A sourcebook. New York, NY: McGraw-Hill.

[4] Derry, S. J., Pea, R. D., Barron, B., Engle, R. A., Erickson, F., Goldman, R., Hall, R. \& Sherin, B. L. (2010). Conducting video research in the learning sciences: Guidance on selection, analysis, technology, and ethics. The Journal of the Learning Sciences, 19(1), 3-53.

[5] Fauziati, E. (2005). Teaching of English as a Foreign Language (TEFL). Surakarta: Muhammadiyah University Press.

[6] Goodwin, C. (2013). The co-operative, transformative organization of human action and knowledge. Journal of pragmatics, 46(1), 8-23.

[7] Gorman, G. E., \& Clayton, P. (2005). Qualitative research for the information professional (2nd ed.). London: Facet

[8] Hall, R. (1999). The organization and development of discursive practices for "having a theory". Discourse Processes, 27(2), 187-218. 
[9] Harmer, J. (1992, 2001, 2007). The Practice of English Language. London: Pearson Longman.

[10] Harrison, B. (1994). The Literate Imagination. London: David Fulton.

[11] Hedge, T. (2000). Teaching and Learning in the Language Classroom. Oxford: Oxford University Press

[12] Huebner, T. (1960). Audio Visual Technique in Foreign Language. New York: Cambridge University Press.

[13] Hughes, R. (2002). Teaching and Researching Speaking. New York: Pearson Education.

[14] Iftakhar, Shampa. (2013). Teaching Speaking Through Public Speaking Course. DOI: $10.3329 /$ sje.v7i0.14473

[15] Krashen, S. D. (1982). Principles and Practice in Second Language Acquisition. New York: Pergamon Press.

[16] Lucas, S. (2001). The Art of Public Speaking (7th ed.). New York: McGrew-Hill Companies.

[17] Lynch, T. (1997). "Nudge, nudge: teacher interventions in task-based learner talk." ELT Journal, 51(4), 317-325.

[18] Morin, R. \& Goebel, J. (2001). Basic vocabulary instruction teaching strategies or word?. Foreign Language Annals, 34 (1), -16

[19] Nunan, D. (1995). Language Teaching Methodology: A Textbook for Teachers. NY: Phoenix Ltd., p. 593.

[20] Patton, M.Q. (1999). Enhancing the quality and credibility of qualitative analysis. Health Sciences Research, 34, 1189-1208.

[21] Polit, D.F., \& Beck, C.T. (2012). Nursing research: Generating and assessing evidence for nursing practice. Philadelphia, PA: Lippincott Williams and Wilkins.

[22] Reedy, Katharine; Parker, Jo, eds. (2018). "Digital Literacy Unpacked" DOI:10.29085/9781783301997 .

[23] Richard, C.J. \& Lockhard, C. (1999). Reflective Teaching in Second Language Classroom. Cambridge: Cambridge University Press

[24] Schmitt, N. (2000). Vocabulary in language teaching. Cambridge: Cambridge University Press.

[25] Scott,J.A.,Jamieson-Noel, D.,\&Asselin,M.(2003). Vocabulary instruction throughout the day in twenty -three Canadian upper-elementaty classrooms. The Elementary School Journal, 103,269-86
[26] Stemler, Steve. (2001). An overview of content analysis. Practical Assessment, Research \& Evaluation, 7(17). Retrieved July 9, 2015 from http://PAREonline.net/getvn.asp?v=7\&n=17.

[27] Thornbury, S. (2005). How to Teach Speaking. Harmer, J. (Ed). London: Longman.

[28] Ur, P. (1991). Discussion that Work. Cambridge: Cambridge University Press

[29] Ur, P. (1996). Language Teaching: Practice and Theory. Cambridge: Cambridge University Press.

[30] Warschauer, Mark; Matuchniak, Tina. (2010). "New Technology and Digital Worlds: Analyzing Evidence of Equity in Access, Use, and Outcomes". Review of Research in Education. 34 (1): 179-225. DOI:10.3102/0091732X09349791 